\title{
Role of Industry and International Organisations in Improving Technical Vocational Education and Training in Nigeria
}

\author{
Ayonmike, Chinyere Shirley ${ }^{1}$ \\ ${ }^{1}$ Department of Technical and Business Education, Delta State University [E-mail: \\ chinyereshirley@ymail.com]
}

\begin{abstract}
This paper reports the findings of a study that delved into the roles of industries and international organisations in improving Technical Vocational Education and Training (TVET) in Nigeria. A survey design was used. The 152 principals of the government technical colleges in the country comprised the population of the study. Seventy-six (representing 50 percent) of these principals were selected to participate in the study. These were selected using stratified random sampling. Data was collected using a 10 -item questionnaire. The data was analysed using means and student-t test at the level of significance $p=.05$. The study revealed that industries and international organizations have great roles to play in improving TVET in the country. Hence, it is recommended that government makes policies that will promote collaboration between TVET institutions and these organisations.
\end{abstract}

Keywords: TVET; Education-Industry partnerships; Reform.

\section{$1 \quad$ Introduction}

TVET is a viable instrument for human capital development, economic progress, and sustainable livelihood. It is skill oriented and involves the acquisition of vocational and occupational skills in various trades and occupations like medicine, engineering, music, fine and applied arts, business, hospitality, oil and gas, ICT, and transport. TVET is about work and training for work. It is an instrument for sustainable industrial development (Abdulmutallib \& Musa, 2014). Technical vocational education and training (TVET) is a notable instrument for producing skilled manpower for various sectors of the nation's economy, thereby creating jobs for her citizens and contributing to wealth generation (Ayonmike, 2016). TVET sometimes also known as Vocational 
Education and Training (VET) or Career and Technical Education (CTE) can be regarded as a means of preparing for occupational fields and effective participation in the world of work. It also implies lifelong learning and preparation for responsible citizenship (Ayonmike, 2016).

According to Idialu (2007) in Abdulmutallib and Musa (2014), TVET is a form of education, training or retraining which is directed towards developing the learner to become productive in paid or self-employment. Japan International Cooperation Agency (JICA, 2001) described TVET as a comprehensive term to cover institution-based formal and non-formal education and training programmes in the technical and vocational institutes.

According to Odugbesan (1995), even before the advent of the British in Nigeria, many communities and cultures had developed their own system of informal, formal and vocational education systems. Vocational education was done through the system of apprenticeship, whereby young boys and men were attached to master craftsmen trades and skills such as carpentry, masonry, blacksmithing, foundry, carving, textile design, and dyeing to mention a few. Such apprentices could spend from three to seven years depending on the trades they were specialising in, the Masters' skill, competence and exposure and the apprentice's individual ability and performance. At the end of such training, the graduate apprentice was assisted by the family to acquire necessary tools and local equipment to start his own trade.

Technical vocational education is recognized as that aspect of education which leads to the acquisition of practical and applied skills as well as basic scientific knowledge that will enable an individual to secure employment in a particular occupation for sustainable livelihood. These skills cannot be acquired in a vacuum but rather in a well-established and functional workshop with the right tools, equipment and machines for effective implementation of TVET programme (Ayonmike, 2016). TVET can only create jobs and generate wealth if giving the required attention by government and stakeholders in the direction of implementation of TVET curriculum at all levels through the provision of the required human and material resources for effective implementation of TVET programmes (Ayonmike, 2016).

However, formal technical education programmes are acquired at primary to university level of education. Odugbesan (1995) opined that TVET outside the universities is offered at a) Local Apprenticeship with Master craftsmen level, b) Prevocational school, c) Vocational Schools (Artisans - Various trades Craftsmen - National Technical Certificate (NTC), d) Technical Colleges Master craftsmen, Advanced Technical Certificate (ANTC), e) Polytechnics and Monotechnics High Technician/Technology Technicians - National Diploma (ND) and Higher National Diploma (HND), f) Colleges of Education (Technical) Technical Teachers -National Certificate in Education NCE (Tech). 
After the national independence in 1960, the products of the nation's formal educational institutions, though considerably increased in number, did not acquire the skilled knowledge and varied technological expertise to meet the specific needs of the industrial sector. It therefore became clear that a link between the industries and the educational institutions must be created in order to meet the needs. One of the ways of bridging this gap was the establishment of the Students Industrial Works Experience Scheme (SIWES) by the Federal Government. In the face of criticism from industries that university and polytechnic graduates lacked the practical skills to undertake serious industrial work, SIWES was established (Odugbesan, 1995). In the light of the above, partnerships with industry if found to be fundamental to securing relevance of training, industry must play an active role and TVET and skills development need to be aligned with workforce needs (Shanti, 2013).

The industries have contributed in improving the competencies of graduates from polytechnics and university through attachment of students under the Students Industrial Works Experience Scheme (SIWES). As well, the industries contributed to education through the Industrial Training Fund (ITF), according to Odugbesan (1995), the Industry Training Fund (ITF) was one of the parastatals established by the Federal Government of Nigeria to create a link between educational institutions and industries. This was done during the second National Development Plan Period (1970-1974). Its enabling Decree, No 47 of 8th October, 1971, defined its objectives as the promotion and encouragement of the acquisition of skills in industry and commerce with a view to generating a pool of indigenous trained persons sufficient to meet the needs of the economy. To be able to generate this needed pool of skilled and efficient indigenous persons, the governing council of the industrial Training Fund is empowered by the decree to: provide facilities for training of persons employed in industry or commerce, approve such courses and facilities provided by other persons; consistently and regularly vet areas of industry or commerce that require special manpower development actions and to recommend the kind of training needed, the standards to be attained, and to ensure that such standards are met; assist persons in finding facilities for training for employment in industry and commerce; and to conduct or assist other persons to conduct research into any matter relating to training in industry.

Industries contributions in other areas include: donation of equipment, machinery and computer components (new and/or used ones) to the institutions for their laboratories and workshops, where funds are limited. As well, special endowments, scholarships and awards are often instituted by private companies and industry to promote their special interest in an institution (Odugbesan, 1995). Similarly, Popoola (1995) posited that the employers' role in establishing cooperation includes the following: need to articulate what skills and specialisation are required; communicate what numbers can be comfortably accommodated; 
provide challenges and real work experience in the planned programme for students on industrial attachment; provide supports services for Vocational Educational Institutions through maintenance service for training equipment, and make their own plants and equipment available to educational institutions; and make available to the institutions specialist instruction through in-house experts and professionals.

According to Lugujjo and Manyindo (1995), co-operation between educational institutions and enterprises in technical and vocational education is manifested in the form of industrial training for students, study tours, organising seminars and workshops and recently, through execution of joint projects between the small scale sector and the institutions. The researchers further opined that a country's technical and vocational training system and its subsequent linkage to enterprises is a decisive factor determining the competitive strength and level of development of its economy, production and maintenance. Skilled workers enhance the quality and efficiency of product development, usage, production and maintenance. The establishment of linkages between technical and vocational training institutions and enterprises provides a solid basis for: curriculum adjustment and reform, student placement for practical experience, staff exchange (staff development), identification of employment opportunities, execution of joint projects, identification and selection of part-time instructors, upgrading of training officers and policy makers' knowledge about the sector, and overall assessment of the success of education and training in meeting the requirements of employers/enterprises.

In terms of building national technical capacity, the accrued benefits to the students in this co-operation is the early exposure to the world of work which enables them to link theory to practical experiences in enterprises. In some cases, students also embark on practical projects to solve problems within the enterprises. In order to achieve all this, the following are proposed: Regular short term courses/seminars should be organised to orient lecturers and trainers, both in enterprises and training institutions, about the mechanisms for co-operation and linkages; strong viable liaison offices/committees should be created in each of the training institutions; and - a National coordinating body should be established, preferably within the framework of National Commission for UNESCO. Similarly, Amaechi (2013) in Ogbunaya \& Ekereobong (2015), suggested the following as strategies for repositioning TVET in Nigeria: improvement of instructional and infrastructural resources in TVET institutions, regular capacity building and training workshops for teachers of TVET; increased funding for TVET institutions for procurement of equipment and more facilities for better learning; better synergy between TVET institutions and industry through exchange programmes; genuine political will by government and education policy makers; improving the conditions of service and regular motivation for TVET teachers and instructors; lastly, regular sensitization to 
improve the public's poor perception of TVET as desirable course option instead of tagging it as inferior course option.

According to Abdulmutallib and Musa (2014), the current global recession is affecting every aspect of human endeavor. This is because a depressed economy like ours in Nigeria is affecting the skills acquisition especially in terms of the vocational and technical education and training for its sustainable industrial development. Nigeria is facing very serious economic problems which are affecting its well-planned policies on TVET because of some factors such as corruption and non-implementation of its well-planned policies on Technical Vocational Education and Training (TVET), there are also more specific problems in technical teaching in Nigeria, but more of these problems have become more pronounced as a result of the poor economy that can never sustain our industrial development in Nigeria. Hence there is need for industries and international organizations to help improve TVET in Nigeria. In this work therefore, international organizations include entities like United Nations, African Union, European Union, and TVET Association, while industries include local and multinational corporations operating in Nigeria. As well, mechanism refers to international organization and industries.

\subsection{Statement of the Problem}

The current economic situation of Nigeria coupled with the continuous fall in crude oil production and prices has affected virtually all the sectors of the country. This economic situation of recession has posed tremendous challenges in the implementation of TVET at all levels due to the fact that TVET is cost intensive as a result of the nature of material and human resources needed for effective implementation TVET programmes. However, there is a paradigm shift from solely relying on government for the funding of TVET in developed nations. As well, other mechanisms such as grants from donor organizations exist in developed countries such as United State of America (USA), the United Kingdom, France, Japan, and Germany among others. The question now is that can alternative sources of funding be used to complement government funding of TVET in Nigeria? This study was conducted to try and respond to this question.

\subsection{Purpose of the Study}

The purpose of the study was to examine the role of stakeholders in improving TVET in Nigeria. Specifically, the study seeks to find out the role of:

1. Industries in improving TVET in Nigeria.

2. International organisations in improving TVET in Nigeria. 


\subsection{Research Questions}

The following research questions guided the study:

1. What are the roles of industries in improving TVET in Nigeria?

2. What are the roles of international organisations in improving TVET in Nigeria?

\subsection{Hypotheses}

The following hypotheses were tested at .05 level of significance:

1. There is no significant difference in the mean response of technical college principals from Northern and Southern Nigeria on the roles of industries in improving TVET in Nigeria.

2. There is no significant difference in the mean response of technical college principals from Northern and Southern Nigeria on the roles of international organisations in improving TVET in Nigeria.

\subsection{Significance of the Study}

This study will be significant to administrators of TVET institutions, TVET lecturers, Students, National Board for Technical Education (NBTE), National Commission for Colleges of Education (NCCE), National Universities Commission (NUC), Industries, International Organisations, Federal Ministry of Education, and State Ministry of Education. The findings of the study will inform the various TVET Stakeholders on how industries and international organization can improve TVET at all levels. Furthermore, the findings of this study will remain a reference point for future researchers in the field of TVET. Lastly, the findings will serve as practical guide in improving TVET through stakeholders such as industries and international organisation.

\section{$2 \quad$ Methodology}

Survey research design was used in this study. The population of the study was all the 152 technical college principals in Nigeria (National Board for Technical Education, nd.). Stratified random sampling technique was used to select 76 principals representing $50 \%$ of technical college principals from Northern and Southern Nigeria, this implies that 34 and 42 technical college principals were selected respectively from Northern and Southern Nigeria making up a total sample of 76 technical college principals. The instrument for data collection was Role of Stakeholders in Improving TVET Questionnaire (RSITVETQ), it is a self-developed 10 item 4-point scale questionnaire of Strongly Agree(4), 
Agree(3), Disagree (2) and Strongly Disagree (1), the questionnaire was validated by three lecturers from Delta State University, Abraka. The reliability of the RSITVETQ was tested by administering 20 copies to TVET lecturers from tertiary institutions in Delta State and Cronbach Alpha technique was used to ascertain the reliability of the instrument which yielded a reliability coefficient of 0.72. Data were collected through the aid of 15 research assistants who were students of the Department of Technical and Business Education, Delta State University, Abraka. Mean was used to analyse the research questions, while ttest was used to test the hypotheses at .05 level of significance. Any mean response of 2.50 will be regarded as Agree, and below 2.50 will be regarded as Disagree. As well, when t-calculated is less than t-critical, the hypothesis will be accepted, and when t-calculated is greater than t-critical, the hypothesis will be rejected.

\section{$3 \quad$ Findings and Discussion}

The findings of the study are presented according to the research questions and hypotheses that guided the study.

\subsection{Roles of Industries in Improving TVET in Nigeria}

The findings on the roles of industries in improving TVET in Nigeria are shown in Tables 1 and 2.

Table 1: Mean Scores of Technical College Principals on the roles of Industries in improving TVET

\begin{tabular}{|c|c|c|c|c|}
\hline \multirow{2}{*}{ What are the roles of industries in: } & \multicolumn{2}{|c|}{$\begin{array}{l}\text { Northern Technical } \\
\text { College Principals }(\mathrm{N}=34)\end{array}$} & \multicolumn{2}{|c|}{$\begin{array}{l}\text { Southern Technical } \\
\text { College Principals ( } N=42\end{array}$} \\
\hline & Mean & Remark & Mean & Remark \\
\hline $\begin{array}{l}\text { Provision of infrastructural facilities in } \\
\text { TVET institutions. }\end{array}$ & 2.78 & Agree & 3.12 & Agree \\
\hline $\begin{array}{l}\text { Provision of feedback to TVET } \\
\text { institutions on the competencies of } \\
\text { TVET graduates. }\end{array}$ & 3.00 & Agree & 3.08 & Agree \\
\hline $\begin{array}{l}\text { Sponsoring of training and retraining } \\
\text { programmes for TVET } \\
\text { teachers/instructors. }\end{array}$ & 3.12 & Agree & 3.31 & Agree \\
\hline $\begin{array}{l}\text { Provision of instructional materials to } \\
\text { TVET institutions. }\end{array}$ & 2.56 & Agree & 2.78 & Agree \\
\hline $\begin{array}{l}\text { Awarding research grants \& scholarships } \\
\text { to TVET students \& instructors. }\end{array}$ & 3.23 & Agree & 3.43 & Agree \\
\hline Grand Mean & & & & \\
\hline
\end{tabular}


Table 1 revealed that industries will help to improve TVET through: Provision of infrastructural facilities in TVET institutions; Provision of feedback to TVET institutions on the competencies of TVET graduates; Sponsoring of training and retraining programmes for TVET teachers/instructors; Provision of instructional materials in TVET institutions and; Awarding grants for research and scholarship to TVET students, teachers and instructors.

These findings are in line with other research findings. Buttressing the findings, Amaechi (2013) in Ogbunaya \& Ekereobong (2015), suggested the following as strategies for repositioning TVET in Nigeria: improvement of instructional and infrastructural resources in TVET institutions, regular capacity building and training workshops for teachers of TVET; increased funding for TVET institutions for procurement of equipment and more facilities for better learning; better synergy between TVET institutions and industry through exchange programmes; genuine political will by government and education policy makers; improving the conditions of service and regular motivation for TVET teachers and instructors; lastly, regular sensitization to improve the public's poor perception of TVET as desirable course option instead of tagging it as inferior course option.

Similarly, in Lugujjo and Manyindo (1995), co-operation between educational institutions and enterprises in technical and vocational education is manifested in the form of industrial training for students, study tours, organising seminars and workshops and recently, through execution of joint projects between the small scale sector and the institutions. The researchers further opined that a country's technical and vocational training system and its subsequent linkage to enterprises is a decisive factor determining the competitive strength and level of development of its economy, production and maintenance. Skilled workers enhance the quality and efficiency of product development, usage, production and maintenance.

The establishment of linkages between technical and vocational training institutions and enterprises provides a solid basis for: curriculum adjustment and reform, student placement for practical experience, staff exchange (staff development), identification of employment opportunities, execution of joint projects, identification and selection of part-time instructors, upgrading of training officers and policy makers' knowledge about the sector, and overall assessment of the success of education and training in meeting the requirements of employers/enterprises. As well, Odugbesan (1995) posited that industries contributions in other areas include: donate equipment, machinery and computer components (new and/or used ones) to the institutions for their laboratories and workshops, where funds are limited. As well, special endowments, scholarships and awards are often instituted by private companies and industry to promote their special interest in an institution. 
Hypothesis 1: There is no significant difference in the mean response of technical college principals from Northern and Southern Nigeria on the roles of industries in improving TVET in Nigeria.

Table 2: Difference in the Principals' mean scores on the roles of industries in improving TVET

\begin{tabular}{|c|c|c|c|c|c|}
\hline Group & $\mathrm{N}$ & Mean & SD & t-cal & Decision \\
\hline Northern Technical College Principals & 5 & 2.94 & 0.27 & 1.260 & Accept \\
\hline Southern Technical College Principals & 5 & 3.14 & 0.25 & & \\
\hline
\end{tabular}

Df $8, t$-crit $=1.860, S D=$ Standard Deviation

Since t-calculated (1.260) is less than t-critical (1.860), hypothesis 1 which stated that there is no significant difference in the mean response of technical college principals from Northern and Southern Nigeria on the roles of industries in improving TVET in Nigeria was accepted.

\subsection{Roles of international Organisations in Improving TVET in Nigeria}

The findings on the roles of international organisations in improving TVET in Nigeria are shown in Tables 3 and 4.

Table 3: Mean Scores of Technical College Principals on the roles of International organisations in improving TVET

\begin{tabular}{|c|c|c|c|c|}
\hline \multirow[t]{2}{*}{$\begin{array}{l}\text { What are the roles of international } \\
\text { organisations in: }\end{array}$} & \multicolumn{2}{|c|}{$\begin{array}{l}\text { Northern } \\
\text { Technical College } \\
\text { Principals }(\mathrm{N}=34)\end{array}$} & \multicolumn{2}{|c|}{$\begin{array}{l}\text { Southern Technical } \\
\text { College Principals } \\
(\mathrm{N}=42)\end{array}$} \\
\hline & Mean & Remark & Mean & Remark \\
\hline $\begin{array}{l}\text { Sharing of global TVET best practices with } \\
\text { TVET institutions in Nigeria }\end{array}$ & 2.65 & Agree & 3.21 & Agree \\
\hline $\begin{array}{l}\text { Organisation of exchange programmes for } \\
\text { TVET students and instructors }\end{array}$ & 3.24 & Agree & 3.08 & Agree \\
\hline $\begin{array}{l}\text { Linking TVET institutions across the globe to } \\
\text { TVET institutions in Nigeria }\end{array}$ & 3.01 & Agree & 2.95 & Agree \\
\hline $\begin{array}{l}\text { Organisation of training workshops, seminars } \\
\text { and conferences for TVET students and } \\
\text { instructors in Nigeria. }\end{array}$ & 2.92 & Agree & 2.87 & Agree \\
\hline $\begin{array}{l}\text { Awarding grants to TVET institutions for } \\
\text { upgrading of facilities. }\end{array}$ & 3.17 & Agree & 3.23 & Agree \\
\hline Grand Mean & 3.00 & & 3.07 & \\
\hline
\end{tabular}

Table 2 revealed that international organization can improve TVET in Nigeria through: Sharing of global TVET best practices with TVET institutions in Nigeria; Organisation of exchange programme for TVET students, teachers, and instructors; Linking TVET institutions across the globe to TVET institutions in Nigeria; Organisation of training workshops, seminar and conferences for TVET 
students, teachers, and instructors from TVET institutions in Nigeria and; Awarding of grant to TVET institutions for upgrading of facilities by international organisation. This findings are in line with previous research findings. In the face of criticism from industries that university and polytechnic graduates lacked the practical skills to undertake serious industrial work, SIWES was established (Odugbesan, 1995). Partnerships with industry is found to be fundamental to securing relevance of training, industry must play an active role and TVET and skills development need to be aligned with workforce needs (Shanti, 2013).

Hypothesis 2: There is no significant difference in the mean response of technical college principals from Northern and Southern Nigeria on the roles of international organisations in improving TVET in Nigeria.

Table 4: Difference in the Principals' mean scores on the roles of international organisations in improving TVET

\begin{tabular}{llllll}
\hline Group & N & Mean & SD & t-cal & Decision \\
\hline Northern Technical College Principals & 5 & 3.00 & 0.23 & 0.558 & Accept \\
Southern Technical College Principals & 5 & 3.07 & 0.16 & & \\
\hline Df $8, t-c r i=1.860$, SD & Standard Deviaton & & & &
\end{tabular}

Df 8, t-crit=1.860, SD = Standard Deviation

Since t-calculated (0.558) is less than t-critical (1.860), hypothesis 1 which stated that there is no significant difference in the mean response of technical college principals from Northern and Southern Nigeria on the roles of industries in improving TVET in Nigeria was accepted.

\section{Conclusion and Recommendations}

Based on the findings of this study, it was concluded that to improve TVET in Nigeria, stakeholders such as industries and international organizations have great role to play through: Sharing of global TVET best practices with TVET institutions in Nigeria; Organisation of exchange programme for TVET students, teachers, and instructors; Linking TVET institutions across the globe to TVET institutions in Nigeria; Organisation of training workshops, seminar and conferences for TVET students, teachers, and instructors from TVET institutions in Nigeria and; Awarding of grant to TVET institutions for upgrading of facilities by international organisations. Furthermore, industries will help to improve TVET through: Provision of infrastructural facilities in TVET institutions; Provision of feedback to TVET institutions on the competencies of TVET graduates; Sponsoring of training and retraining programmes for TVET teachers/instructors; Provision of instructional materials in TVET institutions and; Awarding grants for research and scholarship to TVET students, teachers 
and instructors. The security of the industries is dependent on the manpower development from allied area of study and from the educational institutions, in Nigeria, industrial and technological advancement is crippling, and therefore requires adequate strategies to rescue the situation. Therefore, TVET policy framework and TVET-industry partnership are the instruments necessary to salvage the manpower development of the industry via TVET education programmes, so that there will be continual replacement of competent manpower in the industries. Hence, the following recommendations were made:

1. Government should make policy that will promote collaboration between TVET institutions and stakeholders such as industries and international organizations to improve TVET.

2. Government and TVET boards should include managers of industries and heads of international organizations when planning TVET programme to create lasting relationships.

3. Stakeholders such as industries and international organizations should be given the opportunity to conduct independent assessment of TVET programmes for improvement purpose.

4. TVET administrators should build working relationships with stakeholders such as industries and international organizations to improve TVET programmes.

5. Government and stakeholders such as industries and international organizations should work collectively to improve training methods in TVET institutions.

\section{References}

Abdulmutallib, U. B. \& Musa, A. A. (2014). Strategies for improving technical vocational education and training for the enhancement of public private partnership for sustainable industrial development of Nigeria. ATBU, Journal of Science, Technical \& Education; Vol. 2(2), 105-111.

Ayonmike, C. S. (2016). Technical vocational education and training in Nigeria for job creation and wealth generation: myths and realities. ATBU, Journal of Science, Technology \& Education, 4 (2), 1-8.

JICA (2001). The study of development of a master plan to strengthen technical education in Ghana. Main Report, No, 106 November pp151.

Lugujjo, E. \& Manyindo, B. M. (1995). Uganda: Co-operation links. In UNESCO-UNEVOC (1995). Establishing partnership in technical and vocational education. Co-operation between Educational Institutions and Enterprises in Technical and Vocational Education: A Seminar for Key Personnel from Africa and Asia Berlin, Germany, 02-12 May. 
National Board for Technical Education NBTE (nd). Approved technical colleges in Nigeria. Retrieved $13^{\text {th }}$ February 2017 from http://nbte.gov.ng/techcolleges.html.

Odugbesan, F. A. (1995). Nigeria: The perspective of an educational institution. In UNESCO-UNEVOC (1995). Establishing partnership in technical and vocational education. Co-operation between Educational Institutions and Enterprises in Technical and Vocational Education: A Seminar for Key Personnel from Africa and Asia Berlin, Germany, 02-12 May.

Ogbunaya, T. C. \& Ekereobong, S. U. (2015). Repositioning technical and vocational education and training (TVET) for youth's employment and national security in Nigeria. Journal of Education and Practice, (32), 141-147.

Popoola, B. A. O. (1995). Nigeria: The perspective of an employer. In UNESCOUNEVOC (1995). Establishing partnership in technical and vocational education. Co-operation between Educational Institutions and Enterprises in Technical and Vocational Education: A Seminar for Key Personnel from Africa and Asia Berlin, Germany, 02-12 May.

Shanti, J. (2013). Skill development: Promising approaches in developed countries and emerging economies. Asian Development Bank (ADB) Briefs, No. 19. 